\title{
Severe iatrogenic nostril stenosis
}

\author{
Sir, \\ We have read with great interest, the article $\mathrm{e}^{[1]}$ of Ebrahimi \\ and Shams concerning a case with severe post-operative \\ nostril stenosis in a female patient who underwent \\ multiple - primary and secondary - rhinoplasty \\ operations.
}

The risk of nostril stenosis development after primary rhinoplasty is not high but the cost following it can be, especially important. The appearance of a severe complication following a purely aesthetic surgical intervention can turn a healthy person to a patient with unexpected consequences. We believe that, in such cases where nostril constriction is possible to happen due to nasal valve intra-operative injury, prevention might be the best solution following the basic "better safe than sorry" principle.

Many different internal nasal splints ${ }^{[2-4]}$ have been proposed over time. In similar cases where the nasal valve was affected, we have used a simple, "handmade" internal nasal splint made of X-ray film pieces [Figures 1 and 2]. We have recently used them not only on post-nasal valve injury patients with high risk of nostril stenosis development but also as a standard post-rhinoplasty splint. Their 


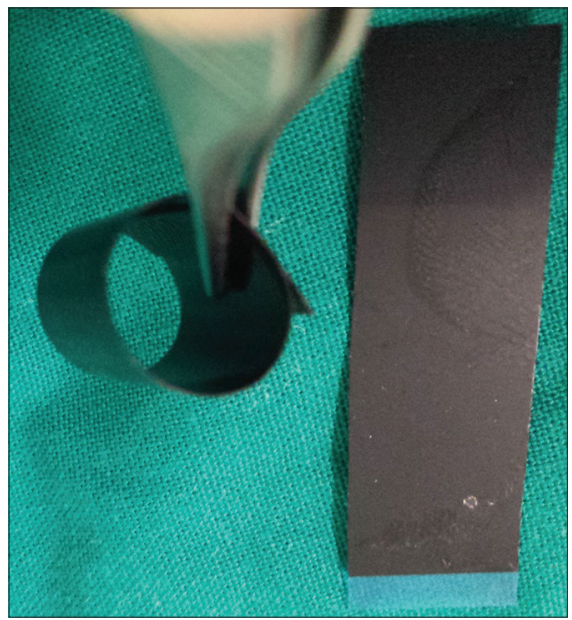

Figure 1: X-ray film piece formed as cylinder splint

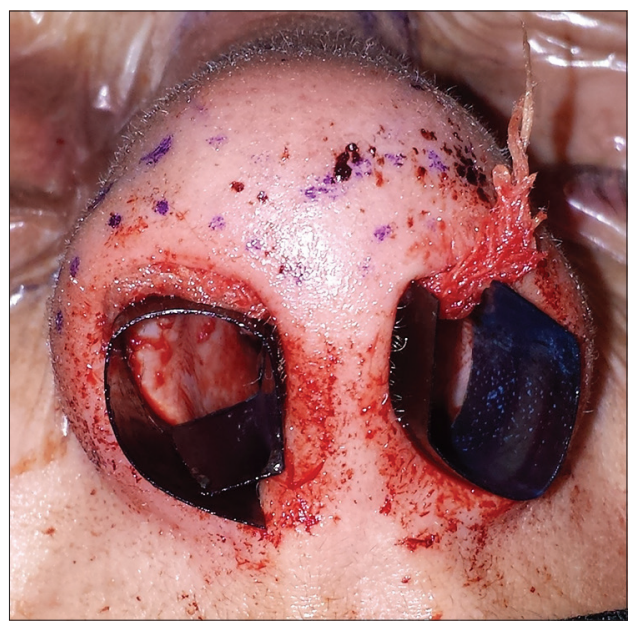

Figure 2: Splints placed into the nostrils post-operatively
Address for correspondence: Dr. Leonidas Pavlidis, Mikroulea 25, 55132, Thessaloniki, Greece. E-mail: leopavlidis@gmail.com

\section{REFERENCES}

1. Ebrahimi A, Shams A. Severe iatrogenic nostril stenosis. Indian J Plast Surg 2015;48:305-8.

2. Wolfe SA, Podda S, Mejia M. Correction of nostril stenosis and alteration of nostril shape with an orthonostric device. Plast Reconstr Surg 2008;121:1974-7.

3. Sekine K, Matsune S, Shiiba K, Kimura M, Okubo K, Kaneshiro T, et al. Treatment of nostril and nasal stenosis due to facial burn using a self-expandable metallic esophageal stent. Auris Nasus Larynx 2015;42:348-52.

4. Egan KK, Kim DW. A novel intranasal stent for functional rhinoplasty and nostril stenosis. Laryngoscope 2005;115:903-9.

This is an open access article distributed under the terms of the Creative Commons Attribution-NonCommercial-ShareAlike 3.0 License, which allows others to remix, tweak, and build upon the work non-commercially, as long as the author is credited and the new creations are licensed under the identical terms.

\begin{tabular}{|l|l|}
\hline \multicolumn{2}{|c|}{ Access this article online } \\
\hline Quick Response Code: & Website: \\
\hline
\end{tabular}

How to cite this article: Pavlidis L, Spyropoulou GA, Chatzinikolaou F, Demiri E. Severe iatrogenic nostril stenosis. Indian J Plast Surg 2016;49:431-2.

(C) 2016 Indian Journal of Plastic Surgery | Published by Wolters Kluwer - Medknow

use is based on the creation of a cylinder splint, taking advantage of elastic properties of an X-ray film. After forming the splint and placing into the nostrils, it tends to unfold maintaining intra-nasal space and keeping the airway open and easily accessible [Figure 2].

\section{Financial support and sponsorship}

Nil.

\section{Conflicts of interest}

There are no conflicts of interest.

\section{Leonidas Pavlidis, Georgia Alexandra Spyropoulou, Fotios Chatzinikolaou ${ }^{1}$, Efterpi Demiri}

Departments of Plastic Surgery and ${ }^{1}$ Forensic Medicine and Toxicology, Aristotle University of Thessaloniki, Thessaloniki, Greece 